\title{
Henrik Ibsen's An Enemy of the People and Eduard Meissner's expulsion from Teplitz
}

\author{
H G Kohler
}

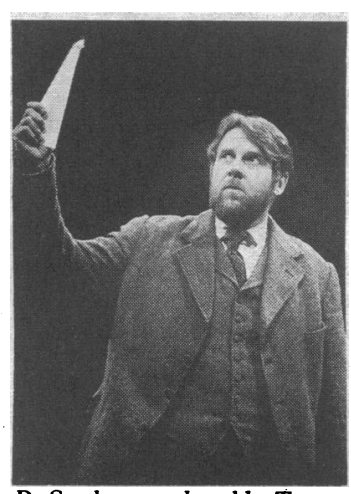

Dr Stockmann played by Tom Wilkinson in the Young Vic production of "An enemy of the people," 1988
Leeds LS16 5PN

H G Kohler, FRCPATH, retired consultant pathologist

BrMed f 1990;300:1123-6
Henrik Ibsen's social drama An Enemy of the People was first performed in 1882. More than 100 years later, in Arthur Miller's version the play could still attract full houses (at the Young Vic and Playhouse in London). The problems raised by Ibsen had existed for a long time and are still with us today.

Many who have seen the play - and especially those with a medical background-may have wondered whether a real incident had inspired the plot and who had served as a model for Dr Thomas Stockmann, the hero of the play. The answer, as for so many works of fiction, is that there was more than one source. But Ibsen's biographers seem to agree that what made him write the play was the story of Dr Eduard Meissner, which he had heard from Eduard's son Alfred when Ibsen was living in Munich between 1875 and 1878 . Alfred Meissner (1822-85) was a frequent visitor to Munich. Although six years older than Ibsen, he is referred to by Ibsen's biographers - and presumably by Ibsen himself-as "young Meissner," probably to distinguish him from his father (whom Ibsen had never met).

Alfred Meissner, like his father, had studied medicine at Prague and qualified; but unlike his father had never practised. The crucial events that he told Ibsen (which are also recorded in his autobiography') took place during the great cholera epidemic of 1831-2that is, nearly 50 years earlier. It is possible that Alfred unwittingly credited his father with ideas and interpretations that belong to the second half of the nineteenth century rather than the first. But in essence we have no grounds to query the veracity of Alfred's story, even though he tended to hero worship his father when he was not quarrelling with him.

\section{Eduard Meissner's travels}

A brief review of Eduard Meissner's life before his sad experience at Teplitz might be of interest. He was born in Dresden in 1785 but grew up in Prague, where his father Gottlieb August Meissner (1753-1807) had been appointed to the chair of aesthetics, the first Protestant to join the professorial staff of this ancient university. Eduard was a brilliant student at Prague Medical School, graduating early in 1808 . The years 1808 to 1812 were taken up by postgraduate studynot only of medicine - in Germany, France, Italy, and Austria before he went to practise in rural areas of eastern Poland and the Ukraine. His motives are a matter of conjecture and are almost certainly multiple and complex, and they may have included a longing for adventure and some compassion for the underdog. Whatever the motives, they had worn thin after four years, and Eduard felt the need, before settling down, to brush up his medicine and to acquaint himself with recent advances.

The principal aim of his "grand tour" was to visit Great Britain. The London hospitals had a great reputation, and Edinburgh's medical school had taken the place of Leiden as the Mecca for medical students. It seems likely that Eduard had considered a visit to London and Edinburgh at an earlier period, perhaps after his spell in Paris, but was prevented from going
In Ibsen's play Dr Stockmann decides to stay and try to re-educate the townspeople, starting with a school for street-urchins:

DR STOCKMANN: ... Just for once, I'm going to try an experiment on these mongrels. You never know what you might find amongst them.

MORTEN: But what are you going to do, when we've grown up into decent and independent-minded men?

DR STOCKMANN: Then you can drive all the wolves out, lads-make sure they all go west!

MRS STOCKMANN: Oh, just so long as it isn't the wolves who go chasing you, Thomas.

DR STOCKMANN: You must be mad, Katherine! Chase me! Now! When I'm the strongest man in the town!

MRS STOCKMANN: The strongest.... ? Now?

DR STOCKMANN: Yes, and I could even go so far as to say that now I'm one of the strongest men in the whole world.

MORTEN: Honestly?

DR STOCKMANN: Sh! You mustn't say anything about it yet. But I've made a great discovery.

MRS STOCKMANN: Not again!

DR STOCKMANN: Yes I have. The thing is, you see, that the strongest man in the world is the man who stands alone.

there by Napoleon's domination of continental Europe.

By 1816 it would have been fairly easy to sail from the Black Sea port of Odessa to London or Leith, but Eduard preferred the more arduous journey by land. He was a passionate traveller and wanted to see as much as possible of the countries he would pass through, including their major medical centres. ${ }^{2}$ So he visited Lvov (then known as Lemberg and part of the Austrian Empire) and Breslau (now called Wroclaw), spent the winter of 1816-17 in Berlin, and then proceeded to visit several Dutch schools.

In the spring of 1817 Eduard crossed the English Channel and spent several weeks in London. He visited every one of the then existing teaching hospitals and one or two of the major non-teaching hospitals as well. He was particularly impressed by both the standard of medical care and the excellent nursing and catering services at Guy's Hospital, but was less impressed by the teaching. Leaving London, he went north but not in a straight line: he managed to see Oxford, Stratford-on-Avon, and Lichfield on his way.

In the early summer of 1817 Meissner arrived in Edinburgh and spent several weeks attending lectures, ward rounds, and small informal meetings. He felt happy in the scholarly atmosphere of Edinburgh - but was by no means uncritical. In Edinburgh and even more so during his tour of the highlands he was impressed by the literacy of the Scottish common people and their thirst for education - of which he had found little evidence in England.

Eduard Meissner was a passionate hiker and had once walked from Paris to Milan, a journey of well over 
$800 \mathrm{~km}$. So it was a matter of course that he visited the highlands on foot. He was surprised and gratified by the high standard of inns and guest houses and by the highlanders' hospitality and sincere friendliness towards strangers.

Eduard Meissner's wife was, according to his own testimony, a native of the Hebrides. ${ }^{3}$ It seems highly likely that they met during his tour of the highlands or perhaps at the end of it. No mention is made in his travel notes of a visit to the Western Isles, nor is there any mention of the bride.

After a visit to Glasgow, which is only very sketchily described, the author returned via Leith to London, sailing by smack, which was much less expensive than the journey by land. By October 1817 Eduard was back on the continent and now had to tackle the problem of setting up practice.

\section{The spa town of Teplitz}

Eduard's wanderlust was probably satisfied by now, and he may well have wished to stay at home. But where was his home? Both Dresden and Prague could claim his loyalty. If he had drawn a straight line to connect the two, it would have cut through the spa town of Teplitz in north west Bohemia. From there Dresden was barely $45 \mathrm{~km}$ to the north, a distance that a fit and experienced hiker like Eduard could manage in one day. Prague was not quite twice as far to the south, perhaps less attractive to attempt on foot, but also within easy reach. The town of Teplitz itself was pleasant and clean, the surrounding countryside full of charm. There was an opening for him, and he seized the chance.

At that time the spa had a history of over 1000 years. For some centuries after their discovery the "hot wells" ("Teplice" in Czech) were administered by a convent of nuns, who acquired considerable skill and experience in using the waters. At the beginning of the medical renaissance the great Paracelsus had visited Teplitz and was much impressed by the therapeutic effects of its hot springs.

The Napoleonic wars-so destructive for most of Europe-turned out to be a boon for Teplitz. The town was spared, even though it sheltered the Austrian high command and was the meeting place of the supreme commanders of the anti-Napoleonic alliance: the Tsar, the King of Prussia, and the Austrian Emperor. With the crowned heads came their generals, aides de camp, diplomatic advisers, and other hangers on. Minor royalty also regarded it a matter of prestige to be at

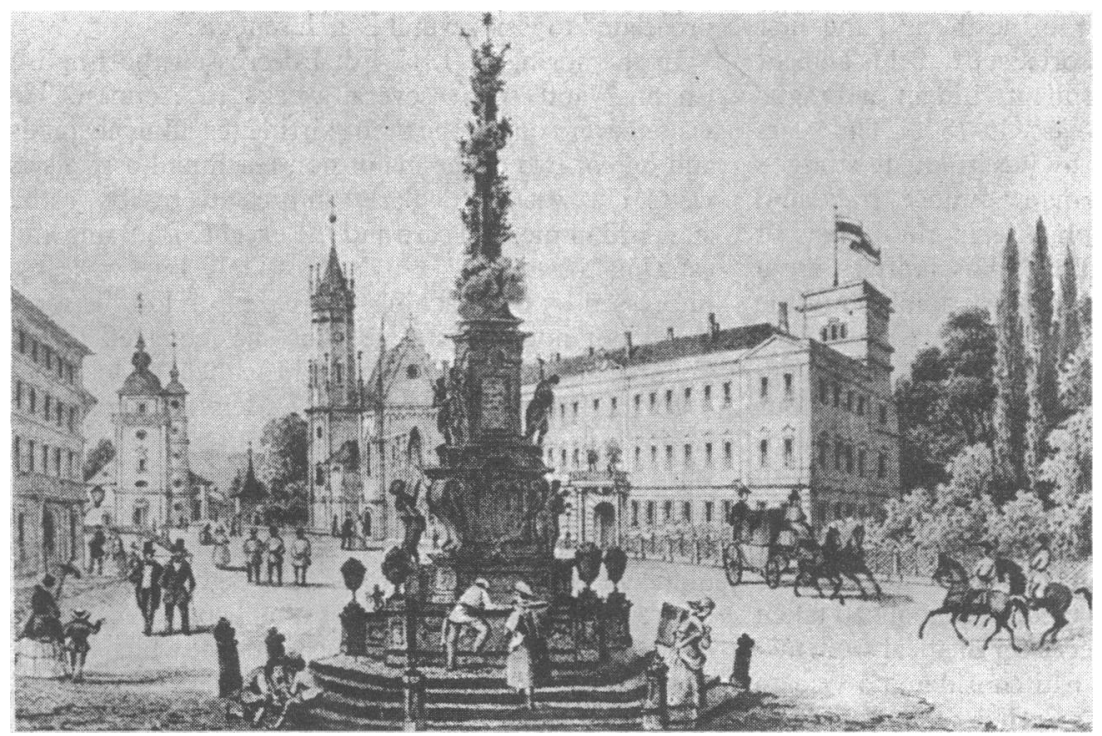

The town of Teplitz was pleasant and clean. .
Teplitz and rub shoulders with the real potentatesand ministers of mini-states, including one $\mathrm{J} \mathrm{W}$ von Goethe, who was well known at Teplitz.

Teplitz proved an agreeable place and many of these visitors returned in peace time-most frequently the King of Prussia, whose morganatic wife preferred easygoing Teplitz to disapproving Berlin. At least one summit meeting was held there after Waterloo, as well as international conferences at ministerial level. Also literati, musicians, and artists came-some to show that they had "arrived," others in the hope of making useful contacts. The 1820 s were a period of boom.

\section{Meissner arrives in Teplitz}

Eduard Meissner, polyglot, widely travelled, and urbane, was the right man for Teplitz. That he was also a competent and highly conscientious physician was a bonus. In addition to his native German and the classical languages he spoke English, French, Italian, Polish, and Russian - a great asset at an international health resort.

Before very long he was able to have a house built to his own design, suitable for entertaining. Mrs Meissner, who in the beginning had only a rudimentary knowledge of German, was always very pleased to welcome anglophone visitors. German men and women of letters would also come and see the Meissners, or even stay with them. Some of these friends Eduard had "inherited" from his father, who was a literary critic, translator, and author. In fact most of the Meissners' social contacts were with visitors, mainly from abroad, rather than local people. $\mathrm{Dr}$ Meissner's professional activity was, of course, not limited to visitors; his practice also covered a whole spectrum of the local population-from the ClaryAldringens (the local land owning family) to the poorest, including those in the ghetto.

Eduard's "splendid isolation" was in part due to his profession. It was aggravated, however, because his wife, even when she had acquired some German, would hardly feel at home in a gossiping party of philistine housewives. Their only child, Alfred, was educated at home - first by his parents, later by a tutor, and so he had no schoolmates, who with so many immigrant families are the first and essential social link with the host population.

In those days of post-Napoleonic political repression and regression it was easy for a man like Eduard Meissner to fall foul of the authorities, or at least to arouse their suspicion. A man of keen and critical intellect who had travelled widely abroad and had foreign friends and visitors was as likely as not to be an opponent - albeit clandestine-of the system. Perhaps having a British born wife was an aggravating factor.

Some form of literary censorship existed in most if not all the states of the German confederation, but it was nowhere as stifling as in Metternich's Austria. Saxony, only about $15 \mathrm{~km}$ away, had a less strict censorship, and literary and political periodicals that were banned in Austria were freely available in Dresden. These periodicals-most of them no more than mildly liberal-found their way into Teplitz alongside other contraband. A new breed of customs officer arose, efficient at sniffing banned literature rather than any other illicitly imported goods. One of these snoopers, acting probably on a tip off, paid the Meissners a domiciliary visit just as Eduard was about to burn some of the incriminating periodicals. The customs officer tried to retrieve the suspect papers from the kitchen range and in doing so badly burnt his fingers. Eduard's medical instincts took over: he dressed and bandaged the injured man with professional skill. Nevertheless, the snooper reported him to higher authority. The doctor-as a "first offender"- 


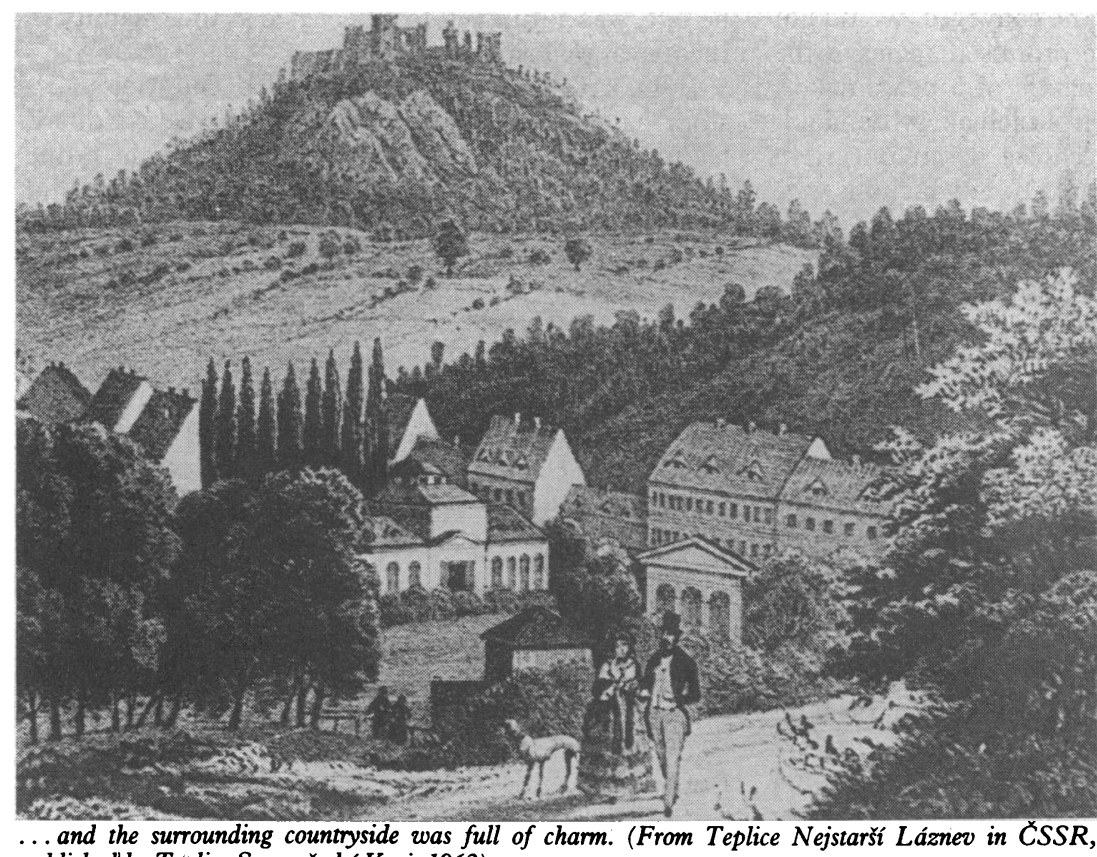

published! by Teplice Severočeské Kraj, 1962)

got away lightly, with a fine to pay, but the local guardians of law and order were pleased because their suspicions had been confirmed. To a wider public Dr Meissner was revealed as vulnerable and fair game for rowdies and trouble makers.

\section{The cholera epidemic}

Europe in the early 1830s was afflicted by the great cholera epidemic, which had spread from India to China and Siberia, reaching central Europe in 1831. The north west of the Habsburg empire, including the health resorts of north west and western Bohemia, at first seemed to escape. That "immunity" was used to advertise the "clean air" of Teplitz. It seems that early in 1832 some sporadic cases occurred in Teplitz, but they were "swept under the carpet."

At that time, more than half a century before the first isolation of the cholera vibrio by Robert Koch, it was widely believed that there were two types of cholera. One was the dreaded epidemic or Asiatic cholera; the other, more benign and sporadic, was named "cholera nostras." (With hindsight we believe that cholera nostras was no more than a non-specific gastroenteritis or enterocolitis.) The diagnosis of cholera nostras was sometimes used to conceal a case of real cholera.

About that time a young countess of the local ClaryAldringen family was being married to a scion of the Radzivils, a Polish princely family. The two families had been friends for generations. The Radzivils were frequent visitors to Teplitz and had appointed Eduard Meissner as their household doctor during their residence.

Now they had come in strength - the family and its various branches, their numerous friends, servants, and cartloads of baggage. Whether the Radzivil party could actually have brought the cholera to Teplitz is a moot point. At the time nobody dared suggest it, and in retrospect it does not seem very likely, but after a large open air party given by the young couple's parents for the people of Teplitz and environs there were several cases of rapidly fatal illness. The civic authorities looked the other way, but the head of the ClaryAldringen family discouraged any further public merrymaking. The claim that Teplitz was free of cholera lost credibility.

One evening in early July Eduard Meissner was called to a patient in the Jewish quarter, a crowded area of narrow streets. The patient had all the clinical manifestations of Asiatic cholera and died the next day. As was his duty, Dr Meissner reported the case to the local authority and demanded that until the house could be disinfected it should be isolated by prohibiting access. This would have meant a sentry being posted there; the mayor would have none of it.

Unlike Peter Stockmann, the mayor in Ibsen's fictional small town, mayor Wolfram of Teplitz was not the doctor's brother, but he was no less two faced and sanctimonious than mayor Stockmann. First he tried to browbeat Eduard into changing the diagnosis to cholera nostras. When Eduard would not budge he shifted the emphasis, pointing to the "disquieting effect" that a cordon sanitaire would have.

Wolfram and Meissner parted without coming to an agreement. It so happened that soon after this encounter Dr Meissner accepted an invitation to lunch with the Radzivils. In retrospect it seems that the invitation had been extended with the intent to sound him out about the cholera risk. Inevitably, the conversation at table drifted to this subject. Naively, or with tongue in cheek, the old princess asked the doctor to reassure her that there was no risk of infection. Such an assurance no honest doctor could give, least of all at a time when an epidemic was raging a short distance away. Eduard mentioned the recently fatal case but also pointed out that the risk of infection was probably not the same in the spacious palace of the ClaryAldringens as in the overcrowded, dilapidated, and insanitary houses of the ghetto. It seems that the Radzivils had already seriously considered departing from Teplitz. Eduard's refusal to "guarantee" their safety from any risk of infection had been the last straw: now a decision was made to leave the next morning.

In a small town like Teplitz the departure of even a single carriage from the squire's mansion would not go unnoticed. When a whole convoy of coaches and carts left, all tongues were set wagging. The departure of the most eminent visitors was bad enough; what was worse, their example would soon be followed by others. The future of Teplitz as a health resort looked not just bleak but black. In the ensuing mood of despair all sorts of rumours, half truths, and superstitions found willing ears. Eduard Meissner must be the culprit and Eduard Meissner-until quite recently highly respected-became the most hated man of Teplitz. What role the mayor played in this shady affair is not recorded, but it is certain that he did not keep his disagreement with Meissner secret. The doctor, however, had no idea of what was going on. Immersed in his professional work and worried about the outbreak of cholera, he was not concerned about gossip. Indeed, he may have been the one person in Teplitz who did not know what was brewing.

In the evening-it was midsummer and the days were long - a crowd collected outside the Meissner's house, first shouting abuse, then throwing stones, smashing windows, and threatening to force the front door. They did not succeed at once, so they abandoned this plan and eventually dispersed. The Meissners, who were not prepared for such an outburst of hostility, had a sleepless night. On the following morning, Eduard reported the events of the previous night to the municipal authority. The mayor, seeming surprised and disgusted, pretended to be sympathetic. $\mathrm{He}$ promsied help and protection against similar molestation-but forgot about it. In the late evening the scenes of the previous night were repeated. The mob was larger now and was armed with sticks, axes, pitchforks, and even old army rifles. The few remaining glass panes,were smashed and the walls were damaged. The family had to protect themselves against stone throwers by a sort of indoor barricade. Around midnight the mayor appeared on the scene in the role of 
mediator. The people outside, he conveyed, would not go away unless Dr Meissner promised to leave the town. Though wearing the mantle of a peacemaker, Wolfram clearly endorsed the troublemakers' demand. Eduard had the unenviable choice of an uncertain future or the risk of being assaulted, to which his wife and child were also exposed. So he accepted what amounted to an ultimatum, especially as their house had been damaged also by a thunderstorm and no longer offered protection from the weather, let alone defence against aggressive force. The mayor told the crowd of this decision, and after their "victory" they dispersed.

The only man who behaved towards Eduard and his family in this crisis in a correct, decent, and humane way was the commanding officer of the local soldiers' convalescent home, the only military establishment at Teplitz. Major von Schwaiger offered them shelter until their departure and also requested from the nearest garrison a detachment of troops to guard the contents of the Meissners' house against looters. (Did he serve as a model for Ibsen's Captain Horster?) Two days later, having packed their possessions on a horse drawn cart, the family left at daybreak. They reached Saaz, some 50 kilometres to the south west, in time for an overnight break, and arrived at Carlsbad the following day, where they found temporary accommodation. There was no hostile feeling towards Eduard Meissner; on the contrary, he was shown great sympathy and consideration by the local people. This, he felt, was a thin veil for their glee at the calamity in their rival watering place.

Ibsen's play ends in a gloomy mood, but Meissner's story has a happier outcome. Within weeks Eduard had established a practice in Carlsbad, which in due course became as busy as the one he had left behind and rather more lucrative. After a few years he limited his professional activity in Carlsbad to four months a year-that is, to "the season"-and spent the rest of the year either travelling in milder climes or in Prague, where his practice was small and select-a matter of prestige rather than a major source of income. Eventually he went to Carlsbad every summer only to take the waters himself and to maintain social contacts with friends and former patients. He died of renal failure aged 83 , the "doyen of the medical fraternity in Prague." $"$

I am indebted to Drs $\mathrm{K}$ Litsch and M Kunštat of the Prague University Archives for information based on Eduard Meissner's student records.

1 Meissner A. Ich traf auch Heine in Paris. Unter Künstlern und Revolutionären in den Metropolen Europas. Berlin: Verlag Der Morgan, 1982. (Abridged reprint of Geschichte meines Lebens, 1882.)

2 Meissner E. Bemerkungen aus dem Taschenbuche eines Arztes während eines Reise von Odessa durch Theile Deutschlands, Hollands, Englands und Schottands. von Odessa

3 Meissner E. Spontaner Somnambulismus, entwickelt in einem lungensüchtigen irchiv für den thierischen magnetismus 1822;10:56-120. 4 [Notices of deaths.] Archiv für Patholog Anatomie etc 1869;46:251.

(Accepted 22 fanuary 1990)

\title{
Everyday Aids and Appliances
}

\section{Bed aids for home nursing}

\author{
A F Travers, P W Belfield
}

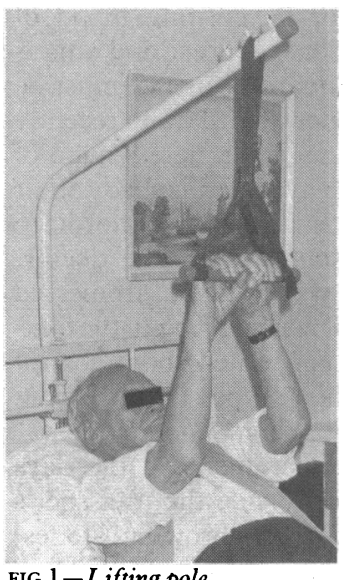

FIG 1-Lifting pole

\section{Department of Medicine}

for the Elderly, St James's University Hospital, Leeds LS9 7TF

A F Travers, MRCP, senior registrar

\section{Medical Department for} the Elderly, Leeds General Infirmary, Leeds LS1 3EX P W Belfield, MRCP consultant physician

Series edited by: Professor Graham Mulley.

Br Med F 1990;300:1126-7
The able bodied among us spend a third of our lives in bed. We take for granted our ability to turn over and get up when we please. In contrast, the disabled patient may spend considerably longer in bed and may have difficulty moving in the bed or getting in and out of it. Many aids and accessories are available and these fall into two broad categories: those for improving mobility around the bed and those for comfort.

\section{Mobility aids}

These aim at improving independence in movement on the bed and help in getting in and out of the bed. The type of bed-for example, a simple divan or a loaned hospital bed-will influence fixation of the aid to the bed. Most aids therefore come in several forms, depending on which bed is used.

Lifting (monkey) poles (fig 1) consist of a cantilever gantry with a support chain or strap from which hangs a handle. They are used to help the patient raise himself or herself off the bed or to move up the bed and their usefulness depends on good strength in the arms. They are most useful for paraplegic patients and other people with problems with their legs. The handle should be large enough for two hands, and the support strap should be adjusted to the correct length, just near enough for the patient to grasp the handle from a lying position. Attendants should take care to avoid head injury on the dangling handle. The lifting pole must be well anchored - that is, clamped to a hospital type bed or screwed to a divan-and its stability should be checked in use. Direct fixing to the ceiling or wall is also possible. Costs range from $£ 40$ to $£ 150$.
Rope ladders (fig 2) enable the user to pull himself or herself up from lying to a sitting position and require strength in both arms as the user "climbs" the ladder, rung by rung. They are fixed to the foot of the bed and usually consist of synthetic ropes with wooden or plastic rungs. They are cheap at $£ 5$ to $£ 10$.

Grab handles (fig 3) help patients to get into and out of bed and are particularly useful for those with unilateral hemiparesis. They also provide something to pull on for movements around the bed. They are adjustable in height and rotate through $360^{\circ}$, locking in eight different positions (for example, the Divan Bed Aid). The most commonly used types are the Lewisham and King's Fund frames, which clamp on to hospital type beds, and the Divan Bed Aid, which

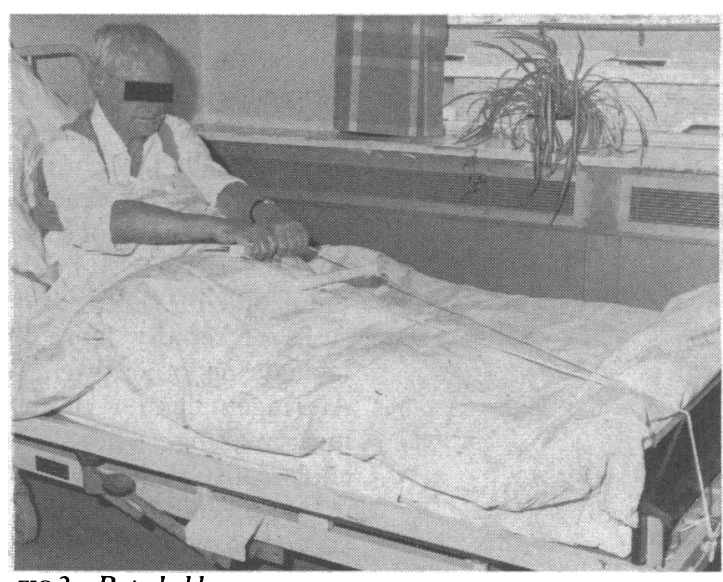

FIG 2-Rope ladder 